\title{
Giardiasis in urban and rural Amazonas, Brazil is driven by zoonotic and cosmopolitan A and B assemblages
}

\author{
Lisiane Lappe dos Reis ${ }^{1 /+}$, Túllio Romão Ribeiro da Silva ${ }^{2}$, Francisco Carlos de Oliveira Braga',3, \\ Naara Macedo do Nascimento ${ }^{1,3}$, Katia Maria Lima de Menezes ${ }^{1}$, Alessandra Ferreira Dales Nava ${ }^{2}$, \\ Natália Aparecida de Souza Lima ${ }^{4}$, Ana Carolina Paulo Vicente ${ }^{5}$ \\ ${ }^{1}$ Fundação Oswaldo Cruz-Fiocruz, Instituto Leônidas \& Maria Deane, Laboratório de Diversidade Microbiana da Amazônia de \\ Importância para a Saúde, Manaus, AM, Brasil \\ ${ }^{2}$ Fundação Oswaldo Cruz-Fiocruz, Instituto Leônidas \& Maria Deane, Laboratório de Ecologia de Doenças Transmissíveis na Amazônia, \\ Manaus, AM, Brasil \\ ${ }^{3}$ Fundação Oswaldo Cruz-Fiocruz, Instituto Leônidas \& Maria Deane, Manaus, AM \\ ${ }^{4}$ Superintendência do Ibama no Amazonas, Centro de Triagem de Animais Silvestres, Manaus, AM, Brasil \\ ${ }^{5}$ Fundação Oswaldo Cruz-Fiocruz, Instituto Oswaldo Cruz, Laboratório de Genética Molecular de Microrganismos, Rio de Janeiro, RJ, Brasil
}

BACKGROUND Giardia duodenalis is a protozoan parasite that infects humans and other mammals and causes giardiasis worldwide. Giardia is genotyped into eight assemblages (A-H), with assemblages A and B considered zoonotic.

OBJECTIVES The aim of this study was to determine the assemblages of G. duodenalis from individuals living in rural and urban areas of the Amazonas State.

METHODS 103 human faecal specimens microscopically positive for the presence of Giardia obtained from four municipalities in Amazonas and four animal faecal specimens were genotyped based on the sequences of two genes, triosephosphate isomerase $(T P I)$ and $\beta$-giardin $(B G)$.

FINDINGS In humans, assemblage A was the most represented with the identification of sub-assemblages AI, AII and AIII based on $B G$ and sub-assemblages AI and AII based on TPI. Similarly, there is a diversity of sub-assemblage B considering $B G$ (B and BIII) and TPI (B, BIII and BIV). In addition, we characterised homogeneous and heterogeneous genotypes comprising assemblages/sub-assemblages $\mathrm{A}$ and $\mathrm{B}$ in individuals from urban and rural areas. Here, for the first time, it was genotyped Giardia that infects animals from the Brazilian Amazon region. We identified sub-assemblage AI in one Ateles paniscus and two Felis catus and sub-assemblage BIV in one Lagothrix cana.

MAIN CONCLUSIONS Therefore, humans and animals from the urban and rural Amazon share Giardia genotypes belonging to assemblages $\mathrm{A}$ and $\mathrm{B}$, which are found in cosmopolitan regions around the world.

Key words: Giardia duodenalis - genotype - animals - human - TPI - BC

Giardia duodenalis (syn. G. intestinalis or G. lamblia) is a protozoan parasite that infects the upper intestinal tract of humans and other animals, causing giardiasis worldwide, which is considered a neglected disease by World Health Organization (WHO) ${ }^{(1)}$ Symptoms in humans such as acute diarrhea may progress to a chronic stage, but most infections remain asymptomatic.(2) In children, giardiasis has a negative impact on their growth and cognitive development. ${ }^{(3)} G$. duodenalis is phylogenetically classified into eight assemblages (A to $\mathrm{H}$ ). Assemblages A and B are zoonotic, and in humans, the prevalence of assemblage B is higher in both low/highincome areas and in different age groups in the world, the exception is Australia where assemblage A is the prevalent. ${ }^{(4)}$ In other mammals, assemblages $\mathrm{C}$ and $\mathrm{D}$ are

doi: 10.1590/0074-02760210280

+ Corresponding author: lisiane.reis@fiocruz.br

(D) https://orcid.org/0000-0002-7968-3718

Received 19 August 2021

Accepted 28 December 2021 specific to dogs and other canids, assemblage $\mathrm{E}$ is found in ungulates including livestock, assemblage $\mathrm{F}$ is found in cats, assemblage $\mathrm{G}$ is found in rodents, and assemblage $\mathrm{H}$ is found in marine mammals, such as pinnipeds family. ${ }^{(5)}$ However, this is a dynamic scenario as recently assemblages $\mathrm{C}, \mathrm{E}$ and $\mathrm{F}$ have also been characterised in human infections. ${ }^{(4,6,7)}$ Based on single nucleotide polymorphisms, assemblages $\mathrm{A}$ and $\mathrm{B}$ have been further defined into sub-assemblages and subtypes, ${ }^{(5)}$ revealing great diversity in $G$. duodenalis. In Brazil, a continental country characterised by many biomes, assemblages A and $\mathrm{B}$ have been described with different prevalence in humans and animals, although studies have been limited to a few human groups, mainly Southeast Brazil. ${ }^{(8)}$

As for the Amazon biome, the prevalence of assemblage B has been noted in two studies conducted in this region based on small indigenous groups..$^{(9,10)}$ To date, there is a gap in terms of animal studies on the occurrence of Giardia in this biome.

Here, we performed a genetic characterisation of $G$. duodenalis in individuals living in rural and urban areas in the state of Amazonas, and found a prevalence of assemblage A over assemblage B. Our study also included animals, and as in humans, assemblage A predominated. 


\section{MATERIALS AND METHODS}

Study area - The study was performed based on samples from four municipalities located in Amazonas State, Brazil, which belong to the Amazon biome (Fig. 1). One urban area: (Manaus $(\mathrm{n}=53)$ - $\left(3^{\circ} 4^{\prime} 25^{\prime}\right.$ 'S, $60^{\circ} 0$ ' $20^{\prime \prime} \mathrm{W}$ ), and the three others rural areas: Iranduba (n = 24) - (Lago do Limão rural community; 0311'0.99"S, $60^{\circ} 20^{\prime} 35.89^{\prime} \mathrm{W}$ ), Autazes ( $\left.=15\right)$ - (São Félix rural community; $\left.03^{\circ} 33^{\prime} 02.8^{\prime \prime} \mathrm{S}, 059^{\circ} 12^{\prime} 05.8^{\prime \prime} \mathrm{W}\right)$ and Boa Vista do Ramos (n = 11) - (2 $\left.58^{\prime} 12^{\prime \prime} \mathrm{S}, 57^{\circ} 35^{\prime} 24^{\prime \prime} \mathrm{W}\right)$, from 2018 to 2019.

Obtaining and analysing stool samples - We obtained, for convenience, 103 human stool sediments positive for $G$. duodenalis of the public health laboratories from these four municipalities and the presence of Giardia was confirmed by microscope observation. Besides, we performed parasitological examination by spontaneous sedimentation and centrifugal-flotation in zinc sulfate ${ }^{(11,12)}$ in 14 animal faecal specimens: $(\mathrm{n}=4)$ are from Ateles paniscus - black spider monkey and Lagothrix cana gray wooly monkey $(\mathrm{n}=2)$ non-human-primates (NHP) from Wild Animal Rehabilitation Centre (CETAS)/ IBAMA and companion cats $(n=8)$ from a veterinary clinic in urban area/Manaus. Cats had no gastrointestinal symptoms. The cats' guardians did not want to perform the parasitological analysis of their stool.
Dna extraction, polymerase chain reaction (PCR) and sequencing - DNA was extracted from Giardia positive samples using QIAamp DNA Stool Mini Kit with minor modifications: lysis buffer temperature to $95^{\circ} \mathrm{C}$ for $15 \mathrm{~min}$, and $200 \mathrm{uL}$ of elution buffer for $10 \mathrm{~min}$ at room temperature. PCR was carried out targeting the triosephosphate isomerase $(T P I)^{(13)}$ and $\beta$-giardin $(B G)^{(14,15)}$ genes. The amplicons were purified using PureLink Quick PCR Purification Kit (Invitrogen, Lithuania), according to the manufacturer's instructions. The fragments were Sanger sequenced using BigDye Terminator Cycle Sequencing Ready Reaction Kit.

Data analysis - The nucleotide sequences were edited in BioEdit software and the consensus sequences were aligned in ClustalW and the phylogenetic analyses were carried out in MEGAX software. The phylogenetic analyses were performed with sequences from humans and animals belonging to $G$. duodenalis assemblages A-F from worldwide and the G. microti and G. muris especies.

Ethics - This study was approved by the local SISBIO NO 67153-3 (general license for animal collection), and by UFAM CEUA NO 017/2020 (Federal University of Amazonas State, ethics committee for animal use), and by UFAM CEP/CAAE NO 41067414.6.00005020 (Federal University of Amazonas State, research ethics committee).

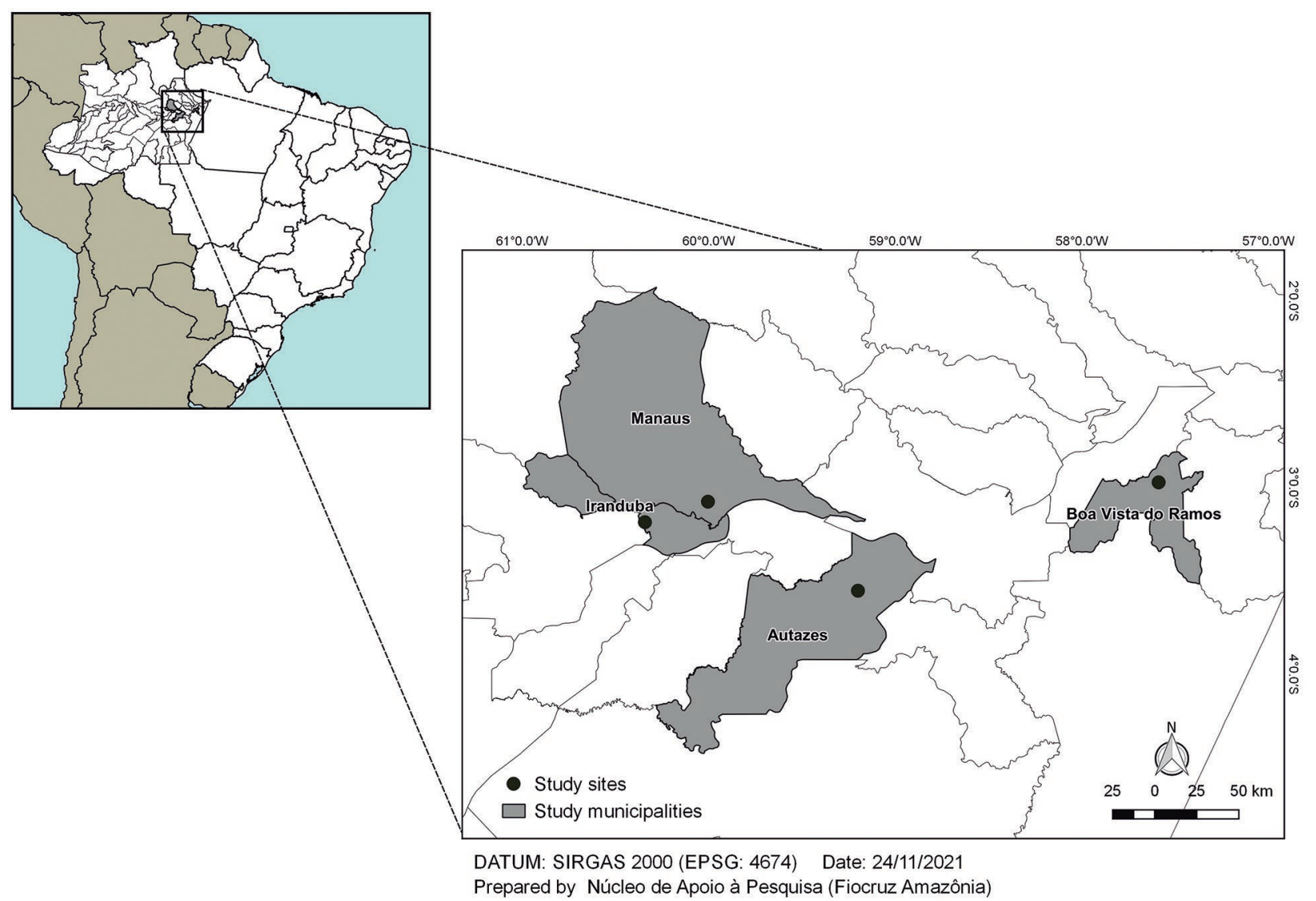

Fig. 1: location of the four study sites, municipalities of Manaus, Boa Vista do Ramos, Iranduba (Lago do Limão community) and Autazes (São Félix community), in Amazonas, Brazil. 
TABLE

Sub-assemblages of Giardia duodenalis from human and animals according to $B G$ and TPI genes

\begin{tabular}{|c|c|c|c|}
\hline \multirow[b]{2}{*}{ Locality } & \multirow[b]{2}{*}{$\begin{array}{l}\text { Id sample } \\
(\mathrm{n}=69)\end{array}$} & \multicolumn{2}{|c|}{ Assemblage } \\
\hline & & $\begin{array}{c}B G \\
(\mathrm{n}=44)\end{array}$ & $\begin{array}{c}T P I \\
(\mathrm{n}=46)\end{array}$ \\
\hline Autazes & $1 \mathrm{SF}$ & - & AI \\
\hline Autazes & $78 \mathrm{SF}$ & - & AI \\
\hline Autazes & 93SF & AI & - \\
\hline Autazes & $82 \mathrm{SF}$ & AI & - \\
\hline Autazes & $77 \mathrm{SF}$ & AI & - \\
\hline Autazes & $75 \mathrm{SF}$ & AI & - \\
\hline Autazes & $47 \mathrm{SF}$ & AI & - \\
\hline Autazes & $43 \mathrm{SF}$ & AI & - \\
\hline Autazes & $22 \mathrm{SF}$ & AI & - \\
\hline Boa Vista do Ramos & $9 B$ & AI & AII \\
\hline Boa Vista do Ramos & 49B & AI & - \\
\hline Boa Vista do Ramos & 14B & AI & - \\
\hline Boa Vista do Ramos & $7 \mathrm{~B}$ & AI & - \\
\hline Boa Vista do Ramos & $6 \mathrm{~B}$ & AI & - \\
\hline Boa Vista do Ramos & $33 \mathrm{~B}$ & AI & - \\
\hline Boa Vista do Ramos & $23 \mathrm{~B}$ & AIII & - \\
\hline Iranduba & $258 \mathrm{~L}$ & - & AI \\
\hline Iranduba & 489L & - & AI \\
\hline Iranduba & $8 \mathrm{~L}$ & - & AI \\
\hline Iranduba & 9L & - & AI \\
\hline Iranduba & $238 \mathrm{~L}$ & - & AII \\
\hline Iranduba & $437 \mathrm{~L}$ & - & AII \\
\hline Iranduba & $18 \mathrm{~L}$ & - & AII \\
\hline Iranduba & $284 \mathrm{~L}$ & - & AII \\
\hline Iranduba & $291 \mathrm{~L}$ & - & AII \\
\hline Iranduba & $287 \mathrm{~L}$ & - & AII \\
\hline Iranduba & $2 \mathrm{~L}$ & AIII & AII \\
\hline Iranduba & $14 \mathrm{~L}$ & AIII & - \\
\hline Iranduba & $29 \mathrm{~L}$ & B & BIII \\
\hline Iranduba & $290 \mathrm{~L}$ & - & B \\
\hline Iranduba & $255 \mathrm{~L}$ & - & B \\
\hline Manaus & $69 \mathrm{~F}$ & B & AI \\
\hline Manaus & $4 \mathrm{M}$ & AI & B \\
\hline Manaus & $72 \mathrm{~F}$ & AI & AI \\
\hline Manaus & $18 \mathrm{M}$ & AI & AI \\
\hline Manaus & $76 \mathrm{~F}$ & AIII & AI \\
\hline Manaus & 22A_CAT* & - & AI \\
\hline Manaus & 700S_NHP* & - & AI \\
\hline Manaus & 113A_CAT* & - & AI \\
\hline Manaus & $11 \mathrm{~F}$ & - & AI \\
\hline Manaus & $63 \mathrm{~F}$ & - & AI \\
\hline
\end{tabular}

\begin{tabular}{|c|c|c|c|}
\hline Manaus & $16 \mathrm{M}$ & AI & - \\
\hline Manaus & $70 \mathrm{~F}$ & AI & - \\
\hline Manaus & $67 \mathrm{~F}$ & AI & - \\
\hline Manaus & $66 \mathrm{~F}$ & AI & - \\
\hline Manaus & $49 \mathrm{~F}$ & AI & - \\
\hline Manaus & $64 \mathrm{~F}$ & AI & - \\
\hline Manaus & $8 \mathrm{~F}$ & AI & - \\
\hline Manaus & $13 \mathrm{M}$ & $\mathrm{AI}$ & AII \\
\hline Manaus & $15 \mathrm{M}$ & AII & AII \\
\hline Manaus & $17 \mathrm{M}$ & AII & AII \\
\hline Manaus & $23 \mathrm{M}$ & AII & AII \\
\hline Manaus & $4 \mathrm{~F}$ & AII & AII \\
\hline Manaus & $20 \mathrm{M}$ & - & AII \\
\hline Manaus & $7 \mathrm{M}$ & - & AII \\
\hline Manaus & $8 \mathrm{M}$ & - & AII \\
\hline Manaus & $2 \mathrm{M}$ & AIII & AII \\
\hline Manaus & $24 \mathrm{M}$ & AIII & AII \\
\hline Manaus & $3 \mathrm{M}$ & AIII & AII \\
\hline Manaus & $9 \mathrm{M}$ & AIII & AII \\
\hline Manaus & $3 \mathrm{~F}$ & - & AII \\
\hline Manaus & $19 \mathrm{M}$ & B & BIII \\
\hline Manaus & $22 \mathrm{M}$ & BIII & B \\
\hline Manaus & $11 \mathrm{M}$ & BIII & B \\
\hline Manaus & $21 \mathrm{M}$ & BIII & BIV \\
\hline Manaus & $2 \mathrm{~F}$ & B & - \\
\hline Manaus & $1 \mathrm{~F}$ & B & - \\
\hline Manaus & $10 \mathrm{M}$ & - & BIII \\
\hline Manaus & 422_NHP* & - & BIV \\
\hline
\end{tabular}

Note: isolates from Iranduba (Lago do Limão community) were obtained in 2018; from Autazes (São Félix community), Boa Vista do Ramos and Manaus were obtained in 2019. *: animal samples; NHP: non-human primate.

\section{RESULTS}

In order to determine the assemblages of $G$. duodenalis from individuals and animals living in rural and urban areas of the Amazonas State (Fig. 1), we screened, microscopically, hundreds of humans and dozens of animal samples. From 107 samples (103 humans and four animals) microscopically Giardia-positive, 64.5\% (69/107) amplified to $B G$ and/or TPI targets (63/humans and four/animals) and, consequently, were included in the present study (Table).

Based on $B G$ and TPI sequences BLAST analyses were conducted and we identified a diversity of subassemblages within the $B G$ sequences (AI, AII, AIII, and BIII) and TPI (AI, AII, BIII, and BIV) (Table). The $\mathrm{AI}(B G)$ sub-assemblage was the most prevalent $(\mathrm{n}=$ 24/36). The second most frequent sub-assemblage was the $\operatorname{AIII}(B G)(\mathrm{n}=8 / 36)$. According to the TPI genotyping, the AII sub-assemblage was the most prevalent ( $\mathrm{n}=$ $21 / 36)$, followed by $\operatorname{AI}(n=15 / 36)$. 


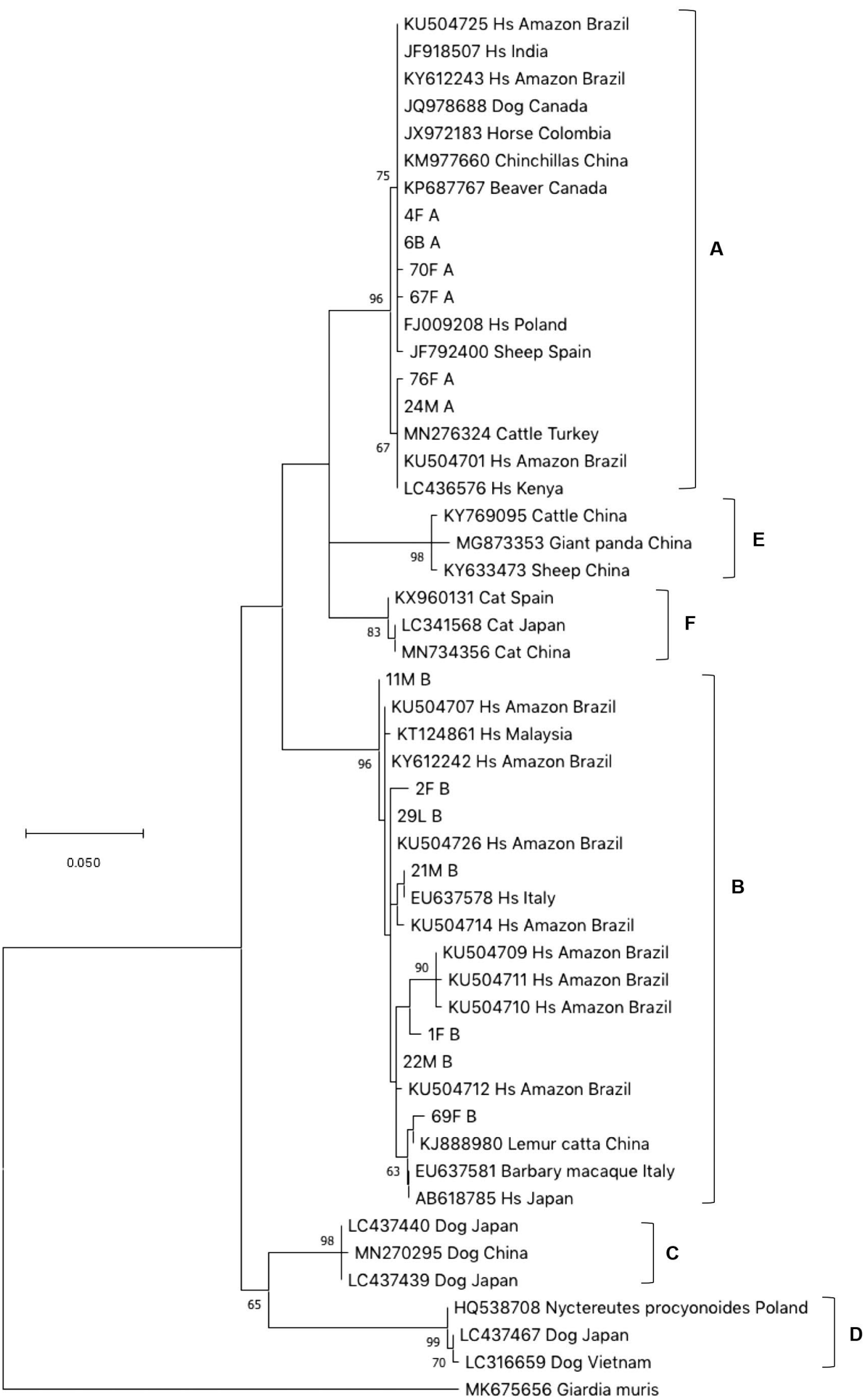

Fig. 2: maximum-likelihood phylogenetic tree based on $B G$ (445 bp). 1,000 Bootstrap values. These sequences are submitted to GenBank (accession numbers: (BG) MZ822137-76). Hs: Homo sapiens. 


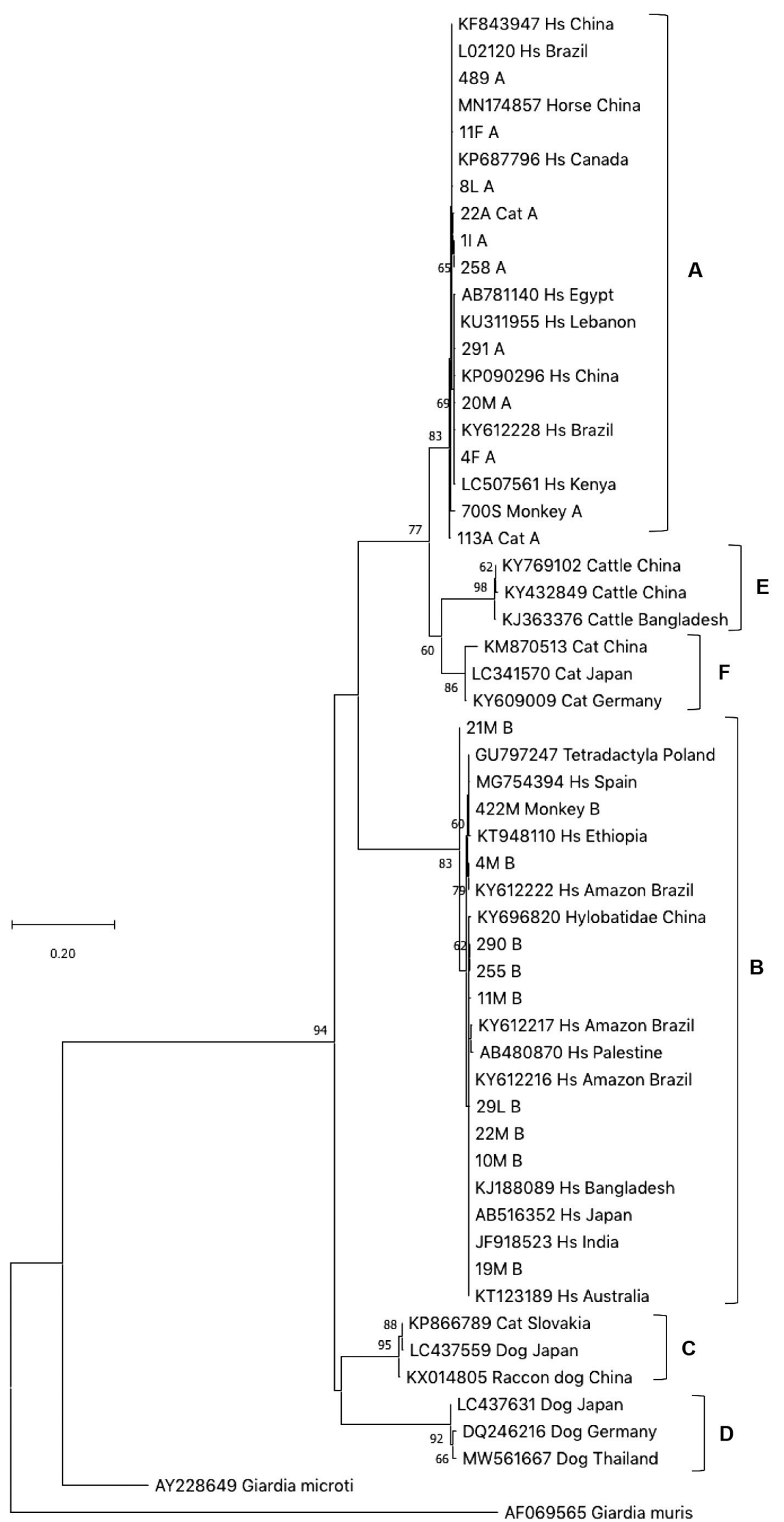

Fig. 3: maximum-likelihood phylogenetic tree based on TPI (428 bp). 1,000 Bootstrap values. These sequences are submitted to GenBank (accession numbers: (TPI) MZ822177-222). Hs: Homo sapiens. 
We characterise homogeneous and heterogeneous genotypes and found the homogeneous genotypes $\mathrm{AI} /$ $\mathrm{AI}(B G / T P I)$ and $\mathrm{AII} / \mathrm{AII}(B G / T P I)$ and a variety of heterogeneous genotypes occur in urban and rural areas. In addition, we also found heterogeneous genotypes between assemblages $\mathrm{A}$ and $\mathrm{B}$ (AI/B and B/AI) (Table).

Within $G$. duodenalis from the four animals (two domestic cats and two NHP of the species A. paniscus and Lagothrix cana), were also identified the assemblages $\mathrm{A}(T P I)$ and $\mathrm{B}(T P I)$. The highest abundance was AI (one NHP, A. paniscus, and two cats). The other sub-assemblage BIV was found in one NHP (L. cana) (Table). The identity values between assemblage A animal sequences: 113A Cat AI, 22A Cat AI, 700S Monkey AI, relative to the closest human sequences (KF843947, L02120, KP687796 and 489 AI) were 99.55\%, 99, 78\%, $99.10 \%$ respectively. The monkey sequence identified as assemblage B (422M Monkey B4) showed an identity of $99.78 \%$ in relation to the closest human sequence (MG754394).

We performed a phylogenetic analysis for $B G$ and $T P I$, and the $B G$ and $T P I$ sequences from this study clustered with worldwide sequences belonging to assemblage A or B (Figs 2-3). About $80 \%$ of the genotypes belonged to assemblage A: (36/44) and (36/46) for $B G$ and $T P I$, respectively, in both urban and rural areas (Table).

\section{DISCUSSION}

This study revealed $G$. duodenalis assemblages A and B in human stools and wild and companion animals, living in Amazonas State, Brazil, which belong to the Amazon biome. In Brazil, the few studies characterising Giardia assemblages suggest regional differences in the prevalence of circulating assemblages. ${ }^{(8,16)}$ Considering only larger population studies, assemblage A was most frequently identified in Southeastern Brazil, ${ }^{(6,17,18)}$ but assemblage $B$ has been identified as prevalent in other Brazilian regions ${ }^{(10,19)}$ Interestingly, in the only genotyping study of G. duodenalis in Amazonas/Brazil, conducted in Santa Izabel do Rio Negro, an area inhabited mainly by indigenous peoples, assemblage $\mathrm{B}$ was predominant. ${ }^{(9)}$ A similar scenario occurred among indigenous peoples in Mato Grosso, Midwest Brazil, where assemblage B was also predominant. ${ }^{(10)}$ Globally, most studies showed a higher prevalence of assemblage $\mathrm{B}^{(20)}$ with the exception of Australia, where A was predominant. ${ }^{(4)}$

The diversity of sub-assemblages identify here, was also been demonstrate in other studies. ${ }^{(10,21,22,23)}$ Likewise, the highest frequency of the AI $(B G)$ sub-assemblage has also been identified in humans in Southeastern Brazil ${ }^{(17,18)}$ however, worldwide, the sub-assemblage $\mathrm{AI}(B G)$ is rare in humans. ${ }^{(24,25,26)}$ The second sub-assemblage most frequent in this study $\operatorname{AIII}(B G)$ is also the most prevalent in the indigenous population of Brazilian Amazon. ${ }^{(9,10)}$ In other Brazilian regions, $\operatorname{AIII}(B G)$ is a rare genotype, identified only in Paraná/ South Brazil $(\mathrm{n}=$ $1 / 10, B G){ }^{(27)}$ Globally, this genotype was identified in Mozambique/Africa $(\mathrm{n}=8 / 14, B G),{ }^{(22)}$ Malaysia $(\mathrm{n}=6 / 18$, $B G)^{(28)}$ and France $(\mathrm{n}=6 / 14, B G) \cdot{ }^{(25)}$ According to the TPI genotyping, the AII sub-assemblage was the most prevalent, followed by AI. This scenario, in which AII(TPI) predominates, has also been shown in other studies in the Southeast Brazilian region, ${ }^{(21,29)}$ and worldwide in Colombia, ${ }^{(23)}$ Czech Republic, ${ }^{(24)}$ France ${ }^{(25)}$ and Malaysia. ${ }^{(28)}$

Having recovered both genes ( $B G$ and $T P I)$ from a number of samples, we were able to characterise homogeneous and heterogeneous genotypes. The homogeneous genotypes $\mathrm{AI} / \mathrm{AI}(B G / T P I)$ and $\operatorname{AII} / \mathrm{AII}(B G /$ $T P I)$ and a variety of heterogeneous genotypes occur in urban and rural areas. Interestingly, all B assemblages were heterogeneous and, in fact, it has been suggested that the $\mathrm{B}$ assemblage is a heterogeneous genotype. ${ }^{(30)}$ In addition, we also found heterogeneous genotypes between assemblages $\mathrm{A}$ and $\mathrm{B}(\mathrm{AI} / \mathrm{B}$ and $\mathrm{B} / \mathrm{AI})$. To extend this scenario, we reanalysed the data of Nunes et al. ${ }^{(9)}$ to identify homogeneous and heterogeneous genotypes in indigenous peoples from the Amazonas. Interestingly, based on the sequences from their study, the presence of three homogeneous $\mathrm{B}(B G / T P I)$ genotypes was detected, at least when these two genes were considered. The most likely hypothesis for the identification of heterogeneous G. duodenalis assemblages is the occurrence of mixed infections, especially in studies of endemic countries. ${ }^{(20)}$ However, recombination events between assemblages should also be considered, as there are a number of clues suggesting Giardia sexual reproduction. ${ }^{(31)}$

The same assemblages A and B also identified in four animals (two domestic cats and two NHP of the species $A$. paniscus and L. cana), according TPI. Interestingly, the highest abundance was AI (one NHP, A. paniscus, and two cats), the second most abundant sub-assemblage among humans in this study. The other sub-assemblage BIV, found in one NHP (L. cana), also was identified in one human/Manaus. This piece of work represents the first data on Giardia assemblages and sub-assemblages in animals in the Brazilian Amazon biome, ${ }^{(8)}$ region extraordinarily rich in biodiversity, having the greatest mammals diversity in Brazil, with many of these animals being unique to the Amazon (endemic). Unexpectedly, the subassemblages (TPI) identified in the wild animals from Amazon biome were also found in animals (dog/cat) in the Southeast region ${ }^{(32,33)}$ and in humans. ${ }^{(21)}$ Worldwide, subassemblages $\mathrm{AI}(T P I)$ have been found in cats/EUA ${ }^{(34)}$ and in dogs, cats, and horses/China. . $^{(35,36)}$ Our results indicate that, in Amazonas, there is a same assemblage circulating between animals and humans. However, this evidence doesn't allow to infer on the transmission of this infection between these humans and animals. Assemblages A and $\mathrm{B}$ are considered zoonotic, ${ }^{(31)}$ and here, in the Amazonas/ Brazil, we also show that humans and animals share $G$. duodenalis genotypes found in cosmopolitan regions around the world.

\section{ACKNOWLEDGEMENTS}

To Fernanda Rodrigues Fonseca from Núcleo de Apoio à Pesquisa (Fiocruz Amazônia) for preparing the map.

\section{AUTHORS' CONTRIBUTION}

LLR and ACPV designed the study; LLR, ACPV and TRRS wrote the manuscript; LLR, ACPV, TRRS, FCOB and NMN performed the analysis; LLR, FCOB, NMN, KMLM, AFDN and NASL contributed to sample collection. All authors read, made suggestions and approved the final version of the manuscript. 


\section{REFERENCES}

1. Savioli L, Smith H, Thompson A. Giardia and Cryptosporidium join the "Neglected Diseases Initiative". Trends Parasitol. 2006; 22(5): $203-8$

2. Certad G, Viscogliosi E, Chabé M, Cacciò SM. Pathogenic mechanisms of Cryptosporidium and Giardia. Trends Parasitol. 2017; 33(7): 561-76.

3. Rogawski ET, Liu J, Platts-Mills JA, Kabir F, Lertsethtakarn P, Siguas M, et al. Use of quantitative molecular diagnostic methods to investigate the effect of enteropathogen infections on linear growth in children in low-resource settings: longitudinal analysis of results from the MAL-ED cohort study. Lancet Glob Health. 2018; 6(12): e1319-28.

4. Buret AG, Cacciò SM, Favennec L, Svärd S. Update on Giardia: Highlights from the seventh International Giardia and Cryptosporidium Conference. Parasite. 2020; 27(49): 2020.

5. Cacciò SM, Lalle M, Svärd SG. Host specificity in the Giardia duodenalis species complex. Infect Genet Evol. 2018; 66: 335-45.

6. Fantinatti M, Bello AR, Fernandes O, Da-Cruz AM. Identification of Giardia lamblia assemblage $\mathrm{E}$ in humans points to a new anthropozoonotic cycle. J Infect Dis. 2016; 214(8): 1-26.

7. Garcia-R JC, Ogbuigwe P, Pita AB, Velathanthiri N, Knox MA, Biggs PJ, et al. First report of novel assemblages and mixed infections of Giardia duodenalis in human isolates from New Zealand. Acta Trop. 2021; 220: 105969.

8. Fantinatti M, Gonçalves-Pinto M, Lopes-Oliveira LAP, Da-Cruz AM. Epidemiology of Giardia duodenalis assemblages in Brazil: there is still a long way to go. Mem Inst Oswaldo Cruz. 2020; 115: $1-12$.

9. Nunes BC, Calegar DA, Pavan MG, Jaeger LH, Monteiro KJL, dos Reis ERC, et al. Genetic diversity of Giardia duodenalis circulating in three Brazilian biomes. Infect Genet Evol. 2018; 59(2018): 107-12.

10. Köster PC, Malheiros AF, Shaw JJ, Balasegaram S, Prendergast A, Lucaccioni H, et al. Multilocus genotyping of Giardia duodenalis in mostly asymptomatic indigenous people from the Tapirapé tribe, Brazilian Amazon. Pathogens. 2021; 10(2): 1-32.

11. Hoffman WA, Pons JA, Janer JL. The sedimentation concentration method in Schistosomiasis mansoni. J Public Health Trop Med. 1934; 9: 281-98.

12. Faust EC, D'Antoni JS, Odon V. A critical study of clinical laboratory technics for the diagnosis of protozoan cysts and helminth eggs in feces. Am J Trop Med Hyg. 1938; 18: 169-8.

13. Sulaiman IM, Fayer R, Bern C, Gilman RH, Trout JM, Schantz PM, et al. Triosephosphate isomerase gen characterization and potential zoonotic transmission of Giardia duodenalis. Emerg Infect Dis. 2003; 9(11): 1444-52.

14. Cacciò SM, Giacomo M, Pozio E. Sequence analysis of the b giardin gene and development of a polymerase chain reaction - restriction fragment length polymorphism assay to genotype Giardia duodenalis cysts from human faecal samples q. Int $\mathrm{J}$ Parasitol. 2002; 32: 1023-30.

15. Lalle M, Jimenez-Cardosa E, Cacciò SM, Pozio E. Genotyping of Giardia duodenalis from humans and dogs from Mexico using a $\beta$-giardin nested polymerase chain reaction assay. J Parasitol. 2005; 91(1): 203-5.

16. Coelho CH, Durigan M, Leal DAG, Schneider AB, Franco RMB, Singer SM. Giardiasis as a neglected disease in Brazil: systematic review of 20 years of publications. PLoS Negl Trop Dis. 2017; 11(10): 1-22.

17. Volotão AC, Costa-Macedo LM, Haddad FSM, Brandão A, Peralta
JM, Fernandes O. Genotyping of Giardia duodenalis from human and animal samples from Brazil using $\beta$-giardin gene: a phylogenetic analysis. Acta Trop. 2007; 102(1): 10-9.

18. Volotão AC, Ramos NMD, Fantinatti M, de Moraes MVP, Atique Netto H, Storti-Melo LM, et al. Giardiasis as zoonosis: between proof of principle and paradigm in the northwestern region of São Paulo State, Brazil. Brazilian J Infect Dis. 2011; 15(4): 382-3.

19. Colli CM, Bezagio RC, Nishi L, Bignotto TS, Ferreira ÉC, Falavigna-Guilherme AL, et al. Identical assemblage of Giardia duodenalis in humans, animals and vegetables in an urban area in Southern Brazil indicates a relationship among them. PLoS One. 2015; 10(3): 1-12.

20. Ryan U, Cacciò SM. Zoonotic potential of Giardia. Int J Parasitol. 2013; 43(12-13): 943-56

21. Durigan M, Ciampi-Guillardi M, Rodrigues RCA, Greinert-Goulart JA, Siqueira-Castro ICV, Leal DAG, et al. Population genetic analysis of Giardia duodenalis: genetic diversity and haplotype sharing between clinical and environmental sources. Microbiology. 2017; 6(2): 1-11

22. Messa A, Köster PC, Garrine M, Gilchrist C, Bartelt LA, Nhampossa T, et al. Molecular diversity of Giardia duodenalis in children under 5 years from the manhiça district, southern mozambique enrolled in a matched case-control study on the aetiology of diarrhoea. PLoS Negl Trop Dis. 2021; 15(1): 1-24.

23. Hernández PC, Morales L, Chaparro-Olaya J, Sarmiento D, Jaramillo JF, Ordoñez GA, et al. Intestinal parasitic infections and associated factors in children of three rural schools in Colombia. A cross-sectional study. PLoS One. 2019; 14(7): 1-19.

24. Lecová L, Weisz F, Tůmová P, Tolarová V, Nohýnková E. The first multilocus genotype analysis of Giardia intestinalis in humans in the Czech Republic. Parasitology. 2018; 145(12): 1577-87.

25. Bonhomme J, Le Goff L, Lemée V, Gargala G, Ballet JJ, Favennec L. Limitations of $t p i$ and $b g$ genes sub-genotyping for characterization of human Giardia duodenalis isolates. Parasitol Int. 2011; 60(3): $327-30$

26. Khan SM, Debnath C, Pramanik AK, Xiao L, Nozaki T, Ganguly S. Molecular evidence for zoonotic transmission of Giardia duodenalis among dairy farm workers in West Bengal, India. Vet Parasitol. 2011; 178(3-4): 342-5

27. Seguí R, Muñoz-Antoli C, Klisiowicz DR, Oishi CY, Köster PC, De Lucio A, et al. Prevalence of intestinal parasites, with emphasis on the molecular epidemiology of Giardia duodenalis and Blastocystis sp., in the Paranaguá Bay, Brazil: a community survey. Parasit Vectors. 2018; 11(1): 1-19.

28. Huey CS, Mahdy MAK, Al-Mekhlafi HM, Nasr NA, Lim YAL, Mahmud R, et al. Multilocus genotyping of Giardia duodenalis in Malaysia. Infect Genet Evol. 2013; 17: 269-76.

29. Scalia LAM, Fava NMN, Soares RM, Limongi JE, da Cunha MJR, Pena IF, et al. Multilocus genotyping of Giardia duodenalis in Brazilian children. Trans R Soc Trop Med Hyg. 2016; 110(6): 343-9.

30. Cacciò SM, Beck R, Lalle M, Marinculic A, Pozio E. Multilocus genotyping of Giardia duodenalis reveals striking differences between assemblages A and B. Int J Parasitol. 2008; 38(13): 1523-31.

31. Capewell P, Krumrie S, Katzer F, Alexander CL, Weir W. Molecular epidemiology of Giardia infections in the Genomic Era. Trends Parasitol. 2021; 37(2): 142-53.

32. Durigan M, Abreu AG, Zucchi MI, Franco RMB, De Souza AP. Genetic diversity of Giardia duodenalis: multilocus genotyping reveals zoonotic potential between clinical and environmental sources in a metropolitan region of Brazil. PLoS One. 2014; 9(12): 1-27.

33. Fava NMN, Soares RM, Scalia LAM, Kalapothakis E, Pena IF, Vieira CU, et al. Performance of glutamate dehydrogenase and tri- 
ose phosphate isomerase genes in the analysis of genotypic variability of isolates of Giardia duodenalis from livestocks. Biomed Res Int. 2013; 2013: 1-9.

34. Saleh MN, Lindsay DS, Leib MS, Zajac AM. Giardia duodenalis assemblages in cats from Virginia, USA. Vet Parasitol Reg Stud Reports. 2019; 15: 100257.
35. Pan W, Wang M, Abdullahi AY, Fu Y, Yan X, Yang F, et al. Prevalence and genotypes of Giardia lamblia from stray dogs and cats in Guangdong, China. Vet Parasitol Reg Stud Reports. 2018; 13: 30-4.

36. Qi M, Ji X, Zhang Y, Wei Z, Jing B, Zhang L, et al. Prevalence and multilocus analysis of Giardia duodenalis in racehorses in China. Parasitol Res. 2020; 119(2): 483-90. 